\title{
The effect of program for small collective games on the level of social interaction and aggressive behavior for children affected with Alexithymia "Dr / Aliaa Abdel Moneim Ibrahim
}

\section{Introduction and problem of research}

The child is born equipped with several instincts and tendencies transmitted to him by heredity, and driven by instinct to behave a certain behavior, to achieve a particular purpose, In the present age, which welling up lot of developments in the various fields, the communities interest in preparing their children with an integrated form, to meet those challenges and to keep abreast of the new century variables.

Sociologists and anthropology indicates that, cultural and social preparation of the child happens through play, games that help to social growth, the child while playing discovers his responsibility towards the community and the need for dependency .

to exercise leadership, success, and a sense of belonging, Also learn how to face satisfaction situations, defeat, cooperation that achieved during playing, love, brotherhood, self-realization, and respect the rights of others.(3.25).

Campbell (2000) has found that, aggressive Children are able to interpret the social directories as provocative and respond even more aggressively in the neutral attitudes, onset children are ostracized often by their friends or colleagues, and this pushes the child to enhance deviant behaviors, and the aggressive children who are hostile society are unable to make social interaction, or establishment of successful social relationships with adults and are less likely to obey to the authority of adults.(30-15).

Some children need social skills, or they will become isolated socially. Children who are engaged in behaviors that reveal the existence of problems, it is believed that they have deficits in the

Assistant Professor, Department of Basic Sciences, Faculty of Kindergarten, AlFayoum University

Assiut Journal For Sport Science Arts 
dealing with the social information system, people who suffer from deficiencies in the ability to identify emotions and describe as alexithymia, more isolated and aggressive, but also avoid most social situations, which require them to talk about their own feelings, and describe them to others, and to determine their opinions and ideas. (5:62) (30:26-32)

Levine (2007) refers to some children can have social difficulties, and emotionally charged, but their academic performance falls under the scope of the ordinary, and others can have these two types of difficulties: Academic difficulties, social and emotional difficulties, and others are social emotional difficulties as a result of academic difficulties, This entails in all cases the appearance of some behavioral problems. (31: 240-246).

That social interaction is a participation process between children, through everyday situations, and is worth noting that social interaction based on the socialization process, whereas the individual can gain through it acceptable social behavior patterns, and also acquires common trends in society, so the social interaction plays an important role in the social development process, for children whether they are normal or with special needs, which equips them to learn social skills, expertise, language, and kinetic, as well as appropriate ways to express feelings, and emotions.(8:11).

Play therapy can be used to play with the children either individually or collectively, depending on the problems that the child is suffering from them, if it was associated with adaptation prefer it is to use the collective pattern, While if these problems are the kind that is linked to emotional turbulence it is preferable to use individual pattern to be available in both cases the types or different forms of games, and The Safe Play tools, until the child does not harm himself or other colleagues,.

Taking into account the exchange between the two types from time to time, and this is available in the intramural sports that are interesting and attractive, so that they learn independent behavioral performance, social interaction can also reduce 
their aggressive behavior and helps them to integrate with others.(1:74)(9:51)(28:51).

Assistant Professor,

Department of Basic Sciences

- Faculty of Kindergarten -

Fayoum University.

Through what is seen by

me reseash, from scientific references and previous studies, such as study of Nicole Rosberash (2013) (33) entitled " the relationship between Alolixitemia, and invest the body tattooed and exposure to traumatic for young university, study of Mohammed Shaaban Ahmed (2015) (17) entitled " The effect of behavioral emotional rational therapy, in the treatment of Alalixitemia for a sample of university students who are retarded of study, study of Mahmoud Suleiman Shehata (2013) (21) entitled " the effectiveness of behavioral cognitive therapy in relieving Alexithymia, in children with learning difficulties. And the study of Brittany Brepetta (2012) (27) entitled "regulate emotion between Alexithymia and eating disorders, the study of Marc Lovis (2012) (32) entitled" Alexithymia and control of the lunging and the risk of suicide for college students, the study of Sabrina Freund (2012) (35) entitled " test of cognitive, emotional and physiological aspects of Alexithymia, study of Massad Nagah El Rifai Abu Diyar (2011) (22), entitled "development of confrontational methods to reduce the clinical symptoms associated with Alexithymia, for a sample of children with special needs. And The study of Fouad Mohamed Aldaohy (2011) (14) entitled Alexithymia as predictive indicator in symptoms for adolescents, and the study of Mohammed Shaaban Ahmed (2008) (16) entitled " Alexithymia and its relationship to the behavior of the riot for a sample of different educational stages, which refer to the importance of using games to improve the level of social behaviors for the people who were infected with Alexithymia.

I caned that, through my work as asupervisior on kindergarten, playing has a positive and effective role for the children who suffer from feelings disorder (Alexithymia) , taking into account, the link between playing and behavior, which in turn is one of the 
fundamental requirements in the educational field for the development of social interactions which may work to reduce behavioral turbulence , "aggressive behavior" for children, that made the researcher to carry out this study, to identify the impact of the collective small games program on the level of social interaction, and aggressive behavior, for children who infected with Alexithymia.

\section{The research aim :}

The research aims to identify the effect of program for small collective games on the level of social interaction and aggressive behavior for children affected with Alexithymia

\section{.Research hypotheses :}

1- There are statistically significant differences between the averages of pre and post measurements, in the level of aggressive behavior for the children under 6 years of the research sample.
1. the averages of pre and post measurements, in the level of social interaction for the children under 6 years of the research sample.

2. the averages of pre and post measurements, in the level of emotional disorder (Alexithymia) for the children under 6 years of the research sample.

\section{Research procedures Research Method: -}

we used the was used method to design pre and post measurements for one experimental group, as it suits the nature of the research.

\section{The research sample:-}

Community of research included children with disorders of feelings attending the kindergarten in Faculty of kindergarten, Forum university aged (6) years, research sample was chosen with deliberately way, children attending before in the nurseries were 12 children, in addition to (8) Children to conduct the scoping study research. 
Table (1)

The homogeneity of the research sample in growth rates, the level of aggressive behavior and social skills, and the level of alexithymia for The research sample. $(\mathrm{N}=20)$

\begin{tabular}{|c|c|c|c|c|c|}
\hline Parameter & $\begin{array}{c}\text { Measuring } \\
\text { Unit }\end{array}$ & Average & $\begin{array}{l}\text { Standard } \\
\text { deviation }\end{array}$ & Mediator & $\begin{array}{r}\text { Torsion } \\
\text { modulus }\end{array}$ \\
\hline \multicolumn{6}{|l|}{ anthropometric variables } \\
\hline Chronological age & Year & 5.68 & 0.32 & 5.65 & 0.58 \\
\hline Length & $\mathrm{Cm}$ & 110.41 & 0.87 & 110.40 & 0.52 \\
\hline Weight & $\mathrm{Kg}$ & 22.51 & 0.61 & 24.50 & 0.63 \\
\hline \multicolumn{6}{|l|}{ The level of aggression } \\
\hline Frank aggressive behavior & degree & 59.87 & 0.15 & 59.85 & -0.98 \\
\hline General Aggressive behavior & degree & 38.14 & 0.52 & 38.10 & 0.47 \\
\hline Disorderly behavior & degree & 24.62 & 0.47 & 24.60 & 0.62 \\
\hline The ability to self-control & degree & 7.25 & 0.98 & 7.20 & -0.87 \\
\hline The whole measure & degree & 129.88 & 8.18 & 129.80 & 0.62 \\
\hline \multicolumn{6}{|l|}{ Social interaction } \\
\hline \multicolumn{6}{|l|}{ The child's behavior } \\
\hline Make friends & degree & 28.18 & 1.12 & 28.10 & 0.28 \\
\hline Empathy for others & degree & 27.36 & 0.96 & 27.15 & 0.71 \\
\hline $\begin{array}{l}\text { Proactive in establishing } \\
\text { relationships with others }\end{array}$ & degree & 30.14 & 0.78 & 30.00 & 0.055 \\
\hline $\begin{array}{l}\text { Cooperation } \\
\text { strengthening relations with } \\
\text { others }\end{array}$ & degree & 34.98 & 1.72 & 34.50 & 0.21 \\
\hline Total first-degree scale & degree & 120.66 & 4.58 & 119.75 & 0.32 \\
\hline \multicolumn{6}{|l|}{ Diagnostic interview } \\
\hline Conversation and dialogue & degree & 6.52 & 0.18 & 6.50 & 0.75 \\
\hline Social understanding & degree & 12.88 & 0.72 & 12.80 & 0.28 \\
\hline $\begin{array}{l}\text { Games interests and favorite } \\
\text { activities }\end{array}$ & degree & 4.92 & 0.11 & 4.90 & 0.23 \\
\hline To act in social situations & degree & 4.18 & 0.28 & 4.10 & 0.71 \\
\hline Total scores second measure & degree & 28.50 & 1.29 & 28.30 & 0.62 \\
\hline The whole measure & degree & 145.16 & 5.87 & 148.05 & 0.82 \\
\hline \multicolumn{6}{|l|}{ alalixitemia } \\
\hline $\begin{array}{l}\text { The difficulty of identifying } \\
\text { sensations }\end{array}$ & degree & 28.62 & 1.10 & 28.60 & 0.62 \\
\hline $\begin{array}{lll}\begin{array}{l}\text { Difficult } \\
\text { sensations }\end{array} & \text { to describe } \\
\end{array}$ & degree & 19.52 & 1.32 & 19.50 & 0.31 \\
\hline Oriented thinking outside & degree & 32.84 & 0.85 & 32.80 & 0.921 \\
\hline Scale group & degree & 80.98 & 0.98 & 80.90 & 0.0265 \\
\hline
\end{tabular}

Table (1) shows that the torsion coefficient confined between (0921 to 0.98). This means that the variables achieve the equinoctial curve, whereas confined between +3 , 
which confirms the extent of heterogeneity for the individuals of sample as a whole.

\section{Data collection tools}

First, devices and tools used in the search- :

The researcher used the following devices to collect data- :

- Alrstamitr device for measuring height in centimeters- .

- A medical balance to measure weight in $\mathrm{kg}$.

- Measuring tape to measure distances.

- Stopwatch to calculate the time.

The following tools are also used in the application of the proposed program:-

- Tennis balls

- Hands balls

- A wooden box

- Swedish seats

- A ruler listed in centimeters

- Hoops

- Metal or wooden keel

- Grain bags

Second, the scale used in the research- :

1- The aggressive behavior test prepared by Said Dubies (1999).

2- The balance of ordinary social interaction for children, and those with special needs, prepared by Mr. Abdul Aziz Al Shakhs(2014).

3- Balance of Toronto Alexithymia "emotional dullness", preparation and translation of "Alaaddin Kafafi"(2011).

Program for small collective games

\section{1- The aim of the program: -}

- Identifying the effect of the use of small games, as a proposal method, to reduce the level of aggressive behavior for children with emotional disorder (Alexithymia).

- $\quad$ The effect of the use of suggested program for small games on social skills in children with emotional disorder (Alexithymia).

\section{2- Program units: -}

To achieve the aims of the study and control variables, which may have an impact on the group, the researcher determines the following: -

- Daily unit of program time is 45 minutes (timeshare).

- Ranging application time of each game between 8 to 10 minutes.

- (3) exercises for the content of basic skills, (2) training and small games, to the content of the daily unit at 
the time of application of each game.

- $\quad$ Suitable suggested program of the small games for children.

\section{3- The program content: -}

The program included the content of the following: -
Suggested

program included (18) Exercise of the calm, (30) warm-up exercise in addition to (20) small games, (10) and exercises to relax. (Attachment 5).

Presentation, discussion, and interpretation of the results First, Results: -

Table (2)

Significance of differences between the pre and post measurements, in the level of aggressive behavior for children affected with alexithymia. $(\mathrm{N}=12)$

\begin{tabular}{|c|c|c|c|c|c|c|c|c|c|}
\hline \multirow{2}{*}{ Parameter } & \multirow{2}{*}{$\begin{array}{c}\text { Measuring } \\
\text { Unit }\end{array}$} & \multicolumn{2}{|c|}{$\begin{array}{c}\text { Pre- } \\
\text { measurement }\end{array}$} & \multicolumn{2}{|c|}{$\begin{array}{c}\text { Post } \\
\text { measurement }\end{array}$} & \multirow{2}{*}{$\begin{array}{c}\text { The } \\
\text { difference } \\
\text { between } \\
\text { two } \\
\text { averages }\end{array}$} & \multirow{2}{*}{$\begin{array}{l}\text { The } \\
\text { improvement } \\
\text { percentage }\end{array}$} & \multirow{2}{*}{$\begin{array}{c}\mathrm{T} \\
\text { Value }\end{array}$} & \multirow{2}{*}{$\begin{array}{c}\text { Significance } \\
\text { level }\end{array}$} \\
\hline & & s & Y & S & Y & & & & \\
\hline $\begin{array}{l}\text { Frank } \\
\text { Aggressive } \\
\text { behavior } \\
\end{array}$ & degree & 59.87 & 0.15 & 35.18 & 8.15 & 24.69 & $70.18 \%$ & 7.85 & Significant \\
\hline $\begin{array}{l}\text { General } \\
\text { Aggressive } \\
\text { behavior }\end{array}$ & degree & 38.14 & 0.52 & 30.14 & 1.36 & 8.00 & $25.69 \%$ & 4.62 & Significant \\
\hline $\begin{array}{l}\text { Disorderly } \\
\text { behavior }\end{array}$ & degree & 24.62 & 0.47 & 15.84 & 2.18 & 8.78 & $55.42 \%$ & 4.68 & Significant \\
\hline $\begin{array}{l}\text { The } \\
\text { ability to } \\
\text { self- } \\
\text { control }\end{array}$ & degree & 7.25 & 0.98 & 4.20 & 0.61 & 3.05 & $72.61 \%$ & 4.11 & Significant \\
\hline $\begin{array}{l}\text { The whole } \\
\text { measure }\end{array}$ & degree & 129.88 & 8.18 & 85.36 & 1.64 & 44.44 & $52.06 \%$ & 3.41 & Significant \\
\hline
\end{tabular}

The tabulated $(\mathrm{T})$ value at the significant level is $0.05=1.714$

Table (2) shows that there are statistically significant differences between the averages of pre and post measurements at the level of aggressive behavior for the children of research sample, whereas the value of $(\mathrm{T})$ more than the value of calculated $(\mathrm{T})$ at the significance level (0.05).

\section{Table (3)}

Significance of differences between pre and post measurement, at the level of Social interaction for the research sample.

$$
\mathbf{N}=\mathbf{1 2}
$$




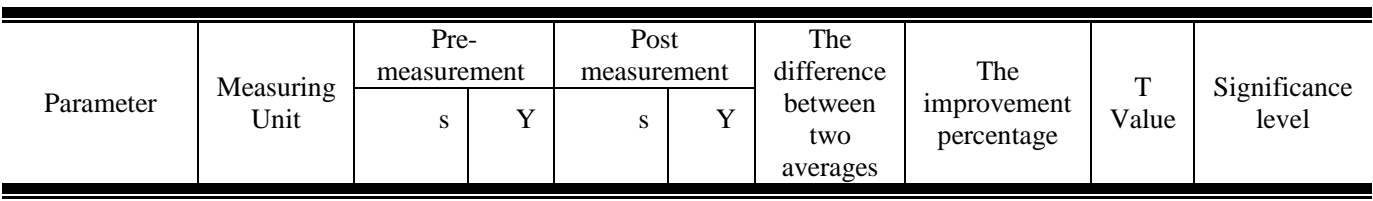

First: The child's behavior

\begin{tabular}{|c|c|c|c|c|c|c|c|c|c|}
\hline Make friends & degree & 6.52 & 0.18 & 44.75 & 2.18 & 16.57 & $58.80 \%$ & 3.69 & Significant \\
\hline $\begin{array}{l}\text { Empathy for } \\
\text { others }\end{array}$ & degree & 12.88 & 0.72 & 45.17 & 0.55 & 17.81 & $65.09 \%$ & 3.21 & Significant \\
\hline $\begin{array}{l}\text { Proactive in } \\
\text { establishing } \\
\text { relationships } \\
\text { with others }\end{array}$ & degree & 4.92 & 0.11 & 48.90 & 1.17 & 18.76 & $62.24 \%$ & 3.58 & Significant \\
\hline $\begin{array}{l}\text { Cooperation } \\
\text { and } \\
\text { strengthening } \\
\text { relations with } \\
\text { others }\end{array}$ & degree & 4.18 & 0.28 & 52.11 & 0.69 & 17.13 & $48.97 \%$ & 3.98 & Significant \\
\hline $\begin{array}{l}\text { Total first- } \\
\text { degree scale }\end{array}$ & degree & 28.50 & 1.29 & 190.93 & 4.59 & 70.27 & $58.23 \%$ & 3.21 & Significant \\
\hline \multicolumn{10}{|c|}{ Second :Diagnostic interview } \\
\hline $\begin{array}{l}\text { Conversation } \\
\text { and dialogue }\end{array}$ & degree & 6.52 & 0.18 & 10.58 & 0.52 & 4.06 & $62.26 \%$ & 3.21 & Significant \\
\hline $\begin{array}{l}\text { Social } \\
\text { understanding }\end{array}$ & degree & 12.88 & 0.72 & 21.58 & 0.87 & 8.70 & $67.54 \%$ & 3.88 & Significant \\
\hline $\begin{array}{l}\text { Games interests } \\
\text { and favorite } \\
\text { activities }\end{array}$ & degree & 4.92 & 0.11 & 8.52 & 0.22 & 3.60 & $73.17 \%$ & 3.24 & Significant \\
\hline $\begin{array}{l}\text { To act in social } \\
\text { situations }\end{array}$ & degree & 4.18 & 0.28 & 8.11 & 0.14 & 3.93 & $94.01 \%$ & 3.98 & Significant \\
\hline $\begin{array}{l}\text { Total scores } \\
\text { second } \\
\text { measure }\end{array}$ & degree & 28.50 & 1.29 & 48.79 & 1.75 & 20.29 & $71.19 \%$ & 3.21 & Significant \\
\hline $\begin{array}{l}\text { The whole } \\
\text { measure }\end{array}$ & degree & 145.16 & 5.87 & 239.72 & 6.34 & 94.56 & $56.14 \%$ & 3.88 & Significant \\
\hline
\end{tabular}

(T) Value in the table at the level of significance $(0.05)=1.714$

Table (3) shows that there are statistically significant differences between the averages of pre and post measurements at the level of social skills, for children of research sample whereas the value of $(\mathrm{T})$ is more than the value of calculated $(\mathrm{T})$ at the significance level (0.05).

Table (4)

Significance of differences between the pre and post measurements, at the level of Alexithymia of research sample. 


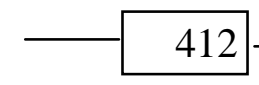

\begin{tabular}{l|c|r|r|r|r|r|r|r|r}
\hline \hline \multirow{2}{*}{ Parameter } & \multirow{2}{*}{$\begin{array}{c}\text { Measuring } \\
\text { Unit }\end{array}$} & \multicolumn{2}{|c|}{$\begin{array}{c}\text { Pre- } \\
\text { measurement }\end{array}$} & \multicolumn{2}{|c|}{$\begin{array}{c}\text { Post } \\
\text { measurement }\end{array}$} & $\begin{array}{c}\text { The } \\
\text { difference } \\
\text { between } \\
\text { two } \\
\text { averages }\end{array}$ & $\begin{array}{c}\text { The } \\
\text { improvement } \\
\text { percentage }\end{array}$ & $\begin{array}{c}\text { T } \\
\text { Value }\end{array}$ & $\begin{array}{c}\text { Significance } \\
\text { level }\end{array}$ \\
\hline $\begin{array}{l}\text { The } \\
\text { difficulty } \\
\text { of } \\
\text { identifying } \\
\text { sensations }\end{array}$ & degree & 28.62 & 1.10 & 19.10 & 0.21 & 9.52 & $49.84 \%$ & 3.25 & Significant \\
\hline $\begin{array}{l}\text { Difficult } \\
\text { to describe } \\
\text { sensations }\end{array}$ & degree & 19.52 & 1.32 & 11.20 & 0.28 & 8.32 & $74.28 \%$ & 3.84 & Significant \\
\hline $\begin{array}{l}\text { Oriented } \\
\text { thinking } \\
\text { outside }\end{array}$ & degree & 32.84 & 0.85 & 19.21 & 0.11 & 13.63 & $70.95 \%$ & 3.61 & Significant \\
\hline $\begin{array}{l}\text { Scale } \\
\text { group }\end{array}$ & degree & 80.98 & 0.98 & 49.51 & 0.74 & 31.47 & $63.56 \%$ & 366.0 & Significant \\
\hline \hline
\end{tabular}

(T) Value in the table at the level of significance $(0.05)=1.714$

Table (4) shows that there are statistically significant differences between the averages of pre and post measurements at the level of Alexithymia balance for the research sample, whereas value of Tabulated (T) is more than the calculated $(\mathrm{T})$ value at the significance level (0.05) and in favor of the post measurement.

Second,

Discussion of results:-

Table (2) shows that there are statistically significant differences between the averages of pre and post measurements at the level of aggressive behavior for the children of research sample, whereas the value of $(\mathrm{T})$ more than the value of calculated $(\mathrm{T})$ at the significance level (0.05), The researcher attributes this improvement to the small games of the suggested collective program, which appeared the influence to reduce some behavioral disorders (aggressive behavior), and the development of social skills mentioned in the research.

Iman Abdullah (2003) stated that these small games take into account the renewal and change in shape, square, circle, locomotive, and the change in the basic situation in which begins the game from, the change in the shape and direction of the child's movement, change in the tools, and the number of participants. $(5: 41)$.

These tinding agreed both Al sayed Abdul Nabi (2004) (2)and, Fouad Aldaoshy (2011)

\section{Assiut Journal For Sport Science Arts}


(14) that there are some general characteristics of individuals suffer from feelings disorder, The extent of the presence of these characteristics or some of the child and the degree of his disability, as well as the extent of the training given. Children infected feelings disorder if they were taught well, they are alike with their peers without disabilities ones, more than their differences among them, and their basic need to play, and kinetic sufficient is not much different, it does not show a big delay in the natural movement and compatibility. (2:41) (14:85).

The results of this study agrees with the study of Iman Abdullah (2003) (5), Adel Abdallah (2004) (9), Rasha Abdul Aziz, and Zeinab Zein Ayesh (2001) (6) in the importance of using the technique to play in improving the level of reduction of aggressive behavior for children.

Thus, the first hypothesis has been achieved, which provides for the existence of statistically significant differences between the averages of pre and post measurements at the level of aggressive behavior for the children (6) years old of the research sample.

Table (3) shows that there are statistically significant differences between the averages of pre and post measurements at the level of social skills, for children of research sample whereas the value of $(\mathrm{T})$ is more than the value of calculated $(\mathrm{T})$ at the significance level (0.05).

The researcher believes that the playing and kinetic activity, are important aspects of modification and guidance to the child's activities, it can enrich which is characterized by the development of the social and psychological values, such as self-control, and the experience of success with its different emotional dimensions, physical activity and playing help to acquire and develop their mental, physical, and social abilities to the maximum extent possible, so that they feel their humanity and their value.

The social interaction means the development and acquisition of child's social skills, help them to integrate effectively and in a manner suitable with members of the community to which he 
belongs, and to increase the volume of cooperation and communication with others, so that their relationships with the comrades are good and active, and acquire the ability to express himself, and in making social and emotional relationships with those around him , through attention to their work and activities and participation, and thus become recognized as vital social relationships that help him compatibility with others.(22:271).

The researcher adds that the increasing attention of researchers during the second half of the twentieth century by the study of the growing sense of social isolation, as a phenomenon spread among individuals in different societies, and attributed it to what this phenomenon of semantics reflect on contemporary human, his sufferings, struggles and crisis, caused by the growing gap between material progress, which goes as a huge rate of progress speed, ethical, social and moral values, which led people to a lack of a sense of security, and peace of mind, about the reality of life.
In this regard, Abdul Saboor Mansour (2003) (10) states that the sports activity saves the integrity and health of body, besides assist in the development of the mind through training on the strength of observation and sound thinking, In addition to the earnings of the individual from the social qualities, through trained him in the exercise of cooperation and participation, requiring a lot of good qualities, as self-control, obedience and a sense of satisfaction and responsibility, leadership, dependency, and also extends to impart the power of determination and courage and proactive, and many other psychological qualities required, and thus created an integrated individual physically, mentally, psychologically and socially, so that ensure big values like, educational and instructional values.(10-12).

In this regard, Amani

Abdel Maksoud (2003) (4) indicate that, in practice games can learn or master some social skills, jointly or individually in the form of small game, can be tolerated in some points of law, such as the number of players or the stadium area, and it 
helps them achieve their cooperative spirit, without regard to the state of competition among children. (4:76).

Thus, the second hypothesis has been achieved, which provides for the existence of statistically significant differences between the averages pre and post measurements at the level of social interaction for the children 6) years old of the research sample.

Table (4) shows that there are statistically significant differences between the averages of pre and post measurements at the level of Alexithymia balance for the research sample, whereas value of Tabulated ( $\mathrm{T}$ ) is more than the calculated $(\mathrm{T})$ value at the significance level (0.05) and in favor of the post measurement, the researcher attributed this improvement to the collective and applicable gaming program on children's research sample.

\section{Fuad}

Muhammad

Aldaoshy (2011) (14) indicates that the spread of Alexithymia percentage ranging between $9 \%-17 \%$, among the different age samples and sex between males more than females, while the percentage of children Alexithymia between 13\%. (14-74). Individuals with Alexithymia have some basic features, considered by some researchers, but most researchers in the field of Alexithymia the basic components of this disorder, which agree both Mohammed Shaban (2015) (17), Mahmoud Shehata (2013) (21) that there are "four basic attributes individuals who suffer from Alexithymia is the difficulty of identifying feelings, and difficult to utter feelings or express them to others, limited imagination, and a pattern of outwardoriented thinking, and this is what she has noticed the researcher with the research sample during the study.

Results of (March Ovens)(2012) Study confirms that individuals who suffer from Alexithymia, also suffer from a lack of self-confidence and a sense of psychological abuse, a much higher degree than their parents, and find it difficult to use some emotional methods in the face of stresses, as well as some of the psychological and behavioral traits characteristic of 
individuals who suffer from Alexithymia, a semi-permanent tendency to lonely and isolated, an impaired ability to make friends, low selfesteem.(102-33).

\section{(Abdul Sabour}

Mansour) (2003) (10) The small games earn individual many social attributes, through trained him in the exercise of cooperation and participation, requiring a lot of good qualities, as self-control, obedience, sense of satisfaction, responsibility, leadership, and dependency, and also extends to impart the power of determination and courage and proactive, and many other psychological qualities required, and thus created an integrated individual physically, mentally, psychologically and socially, so that ensure big educational and instructional values.(12$10)$.

Thus, the third hypothesis has been achieved, which provides for the existence of statistically significant differences between the averages of tribal and dimensional measurements in the level of emotional disorders, Alexithymia in children aged 6 years of the research sample.

\section{Conclusions}

1. Collective small games of the suggested program has a positive effect on aggressive behavior for the children of research sample.

2. Collective small games of the suggested program has a positive effect on social interaction for the children of research sample.

3. collective small games of the suggested program has a positive effect on reduction of alexithymia level for the children of research sample-

\section{Recommendations}

1. Conduct further scientific studies to identify the effect of the application of Small games on the psychological and social characteristics of this phase.

2. The interest in yard games for the kids.

\section{References}

1- Abdul Aziz Alshakhs: "scale social interaction for children", Anglo library Cairo 2014

2- Aladdin Kafafi, Fouad Aldawash: "Toronto scale of Alalixitemia". Anglo library, Cairo 2011.

3- Abdul Saboor Mansour Mohammed 
Introduction to Special Education is the psychology of ordinary upbringing", Zahra Middle Library, Cairo.

4- Adel Abdullah Mohammed (2001): "Cognitive- behavioral psychotherapy", (i 1), Dar alRashad, Cairo.

\section{5- Adel Abdullah}

Mohammed (2004): "sensory disabilities" series Special Needs, Dar al-Rashad, Cairo.

6- Alsayed Abdul Nabi Alsayed (2004): "Educational activities for children with special needs", the AngloEgyptian Library, Cairo.

7- Amani Abdel-Maksoud Abdul Wahab (B. C): "A measure estimate the children's social skills", the AngloEgyptian Library, Cairo

8- Ellen Wadih Farag : "Experience in gaming"; Knowledge facility in Alexandria,C 2.2002 .

9- Fouad Mohamed Aldaohy (2011) :study titled" Alalixitemia a predictive indicator in symptoms among adolescents", Master, Nayef College for Security Sciences, Saudi Arabia.

10- Hisham Abdel Rahman Al Khouly (2010), "the mental health problems of life, 2nd Floor, Arab Renaissance Publishing House, Cairo.
19- Hisham Abdel Rahman Al Khouly (2008) studies and research in psychology and mental health, Renaissance Publishing House Printing and Publishing, Cairo.

20- Iman Abdullah AlBanna: (2003) :"Alalixitemia (difficulty identifying feelings description) and patterns of coping with stress", Faculty of Arts Library, Ain Shams University, Vol 31.

\section{1- Magdy Mohammed}

Desouqy: "A measure estimating the symptoms of chaotic behavior", Anglo library Cairo 2014.

\section{2- Mohammed Shaaban} Ahmed (2008), "Alalixitemia and their relationship to the behavior of the riot among a sample of different educational stages, Master Thesis, Faculty of Education, University of Fayoum.

23- Mohammed Shaaban Ahmed (2015), "the impact of rational emotive behavioral therapy in the treatment of Alalixitemia among a sample of collectors latecomers students academically", PhD thesis, Faculty of Education, University of Fayoum.

24- Mohamed Abdel Tawab Abu Nour (2009) "Analytical 
readings in mental health", home science, Fayoum library. 25- Mohamed Adnan Olwaan (2007): "Autistic children" Cairo, Dar Yazouri scientific publication.

26- Mohammed Nasser (2005): "Special Sports "sports for the disabled and a technical training", (i 3), Dar Ilm, Beirut, Lebanon.

27- Mahmoud Suleiman Shehata (2013), "the effectiveness of cognitive behavioral therapy in relieving Alalixitemia in children with learning difficulties", Master Thesis, Faculty of Education, University of the Suez Canal. 28- Mahana Ghanayem, Hadia Aw Kalila (1987):" Special education for the disabled", the modern scientific library, Mansoura.

29- Massad Naggah Rifai Abu Diyar (2011) :study entitled "Development confrontational methods to reduce the clinical symptoms associated with Olixitemia among a sample of children with symptoms of self", his master, the Women's College of Arts and Sciences and Education, Ain Shams University.

\section{0- Rasha Mohamed} Abdelaziz, Zainab bnt Mohamed Zain Ayesh (2001) :"the psychology of the face of violence against children", the world of books, Cairo.

31- Sami Mahmoud Hassan, Abdul Salam on Alagafash "(2002):" summarized in psychoanalysis", (i 4), Knowledge House, Cairo.

\section{2- Omar Khattab Khalil} (2001): "Effective methods in the treatment of autism." Journal of childhood obstacles - Issue (9) - Al-Azhar University.

33- Osama Riad (2000): "Disabled Sports medical and sports foundations", Cairo, Dar Arab Thought, Cairo. 